\title{
Management and leadership: buccaneering or science?
}

\author{
Hester Nienaber \\ Gerrie Roodt
}

\begin{abstract}
Purpose - This paper aims to determine the views of a select group of manager-students on general management and leadership and whether or not their views correspond to classical management theory.

Design/methodology/approach - An exploratory-descriptive approach was employed. Specifically, a survey was conducted among final-year MBA students of a specific university. These students were all employed in management positions in their respective organisations.

Findings - The students viewed general management and leadership as being the same and their views correspond to the theory underpinning classical management.

Research limitations/implications - Statistically, the findings cannot be generalised beyond the scope of this study due to its exploratory nature. However, the concepts referred to in this study can inform and be tested in further research.

Practical implications - It would seem that there is indeed a body of knowledge underpinning classical management. Mastery of this knowledge could enable managers to ensure the preferred competitive positions of their organisations.

Originality/value - This paper focuses attention anew on classical management and its scientific nature as well as its contribution to the sustained competitive success of organisations.

Keywords General management, Leadership, Students, South Africa

Paper type Research paper

\section{Introduction}

By now, it is generally accepted that management and leadership play a vital role in the competitiveness of firms. As such, these terms were used interchangeably for most of the twentieth century (Kent et al, 2001), when the discipline of classical management was first documented. Pioneers in classical management treat leadership as part of management, since the leadership tasks/activities (generally referred to as command and co-ordination) are deemed an integral part of management (see, inter alia, Fayol, 1949). However, many contemporary authors distinguish between these two concepts in a way that seems to focus on leadership and render management irrelevant (Zaleznik, 1977; Kent et al, 2001; Armandi et al, 2003). However, there appear to be other contemporary authors who share the same sentiments as the seminal classical management authors in this regard (Ulrich et al, 1999).
\end{abstract}

The authors would like to thank Jaqui Sommerville and Judy Coetzee of the Department of Statistics (University of Pretoria) for their assistance in the statistical analysis of this research. 
The documented body of knowledge underpinning classical management, including leadership, is a relatively young discipline (Wren, 2005). Furthermore, most people in management positions have been specifically trained in some technical area rather than management. Hence, it stands to reason that these managers/leaders do not necessarily practice management/leadership as intended by management theory. The reason for this was earlier given as "the lack of a published body of knowledge" (Follett, 1925, in Metcalf and Urwick, 1940). Later on, the reason was given as "the younger group do not know these (original) works; more hear them misinterpreted" (Lillian Gilbreth, 1914 in Spriegel and Myers, 1953). Because of the lack of clarity regarding classical management theory and the consequent gap between theory and practice, management became equated with "buccaneering" at some point (Follett, 1925 in Metcalf and Urwick, 1940).

The question that arises is: do academics and practitioners alike embrace classical management science or do they treat management as buccaneering? Bearing in mind that management may be the most significant task/activity of organisations ensuring success, it is not the only task/activity of organisations.

With the above as background, the authors set out to determine whether there was a gap between classical management as manifested in "general management" and "leadership" theory, and contemporary practice. A literature review is followed by a survey of a select group of manager-students. This is followed by the survey results, which are compared with the literature to determine whether there is a gap between theory and practice. This paper closes with conclusions and recommendations.

\section{Literature review}

Traditionally, that is before the twentieth century, "business" was seen to be synonymous with "trading" which was associated with unscrupulous practices that did not require special intelligence or training (Follett, 1925 in Metcalf and Urwick, 1940). If a person considered his/her child unfit to study for a profession, the child was put into business. Traditional management viewed staff as docile, having no will of their own (McGregor, 1942 in Bennis and Schein, 1966). Hence, they had to be "driven" (Gilbreth, 1914 in Spriegel and Myers, 1953) and treated as children rather than mature adults (Follett, 1925 in Metcalf and Urwick, 1940). The consequence was that traditional management accepted that they had to adopt a paternalistic stance and tell staff when to do what. In essence, traditional management dominated staff and bent their will to that of the "masters" using fear for the masters' gain (Follett, 1925 in Metcalf and Urwick, 1940; Gilbreth, 1914 in Spriegel and Myers, 1953; McGregor, in Bennis and Schein, 1966).

This flawed view of management's role was highlighted from the first publications on classical management (see, inter alia, Owen, 1813; and Babbage, 1832 in Merrill, 1960; Taylor, 1911; Barnard, 1938; Follett, 1925 in Metcalf and Urwick, 1940; Fayol, 1949; Gilbreths in Spriegel and Myers, 1953; Simon, 1962; McGregor in Bennis and Schein, 1966; Drucker, 1955,1989, 2003; Koontz and Weihrich, 1988; Ulrich etal, 1999; McMahon and Carr, 1999; Fells, 2000; Humphreys and Einstein, 2000; O'Connor, 2000; Collins, 2001; Rodriques, 2001; Wren, 2001; Wren etal, 2002; Bruch and Ghoshal, 2004; Wren, 2005). These authors focused on the importance of management in creating an environment in which employees could achieve their full potential while at the same time efficiently achieving the goals of the organisation (see, inter alia, Owen, 1813 in 
Merrill, 1960; Babbage, 1832 in Merrill, 1960; Follett, 1925 in Metcalf and Urwick, 1940; Taylor, 1911; Barnard, 1938; Fayol, 1949; Simon, 1962; Ulrich et at, 1999). Typical themes discussed include:

- Systems theory. The organisation consists of different parts that impact on the functioning of one another; and the organisation is influenced by the broader environment in which it conducts business.

- The organisation is a social setting consisting of people with talents which contribute to the organisation's success.

- The well-being of people, whether on the job or not, is more important than that of machines used in production.

- Productivity is important in wealth creation. Hence, the person most suitable for the job should be employed in that particular position. Furthermore, the abilities of the workers should be honed to ensure they all achieve their full potential and, consequently, engage in the work most interesting to them. Processes and structures also influence productivity. As such, they have to be aligned with the goals of the organisation to ensure efficacy.

This view of management required a shift in the mindset of both management and employees to ensure success in the long run.

In summary, the classical management literature highlights the mutually beneficial relations between management and employees in producing goods and services, at a surplus, to customers.

It is important to note that the classical management authors use the terms "management" and "leadership" interchangeably at all hierarchical levels (be it at the level of foreman, superintendent, manager, director, or CEO) of the organisation (Follett, 1925 in Metcalf and Urwick, 1940; Fayol, 1949; Gilbreths in Spriegel and Myers, 1953; McGregor in Bennis and Schein, 1966; Ulrich et at, 1999). It appears that the term "management" is generally used in connection with tasks/activities such as planning, organising and control, while the term "leadership" is often used in connection with tasks/activities such as command and co-ordination. According to Fayol (1949), the art of command rests on certain personal qualities and a knowledge of general principles of management, while co-ordination relates to according things and actions their rightful proportions and adapting means to ends, bearing in mind the obligations and consequences involved. All of these tasks/activities fall within the scope of the primary management tasks. The idea is that management, including leadership, can energise the group, encourage initiative and innovation and draw from all staff members what they have to offer, while the staff take full responsibility for their contributions, ensuring that the organisation is successful in the long run (Owen, 1813; Babbage, 1832 in Merrill, 1960; Taylor, 1911; Barnard, 1938; Follett, 1925 in Metcalf and Urwick, 1940; Fayol, 1949; Gilbreths in Spriegel and Myers, 1953; Simon, 1962; McGregor, in Bennis and Schein, 1966; Drucker, 1955,1989,2003; Koontz and Weihrich, 1988; Moss-Kanter, 1997; Ulrich et at, 1999; Fells, 2000; Humphreys and Einstein, 2000; O'Connor, 2000; Collins, 2001; Witzel, 2002; Wren et at, 2002; Bruch and Ghoshal, 2004; Wren, 2005).

Since, the mid-1970s, some authors have distinguished between classical management and leadership as two separate concepts (Zaleznik, 1977; Burns, 1978; Bennis and Nanus, 1985; Kotter, 1996, 2001; Tichy, 1997; Kent et at, 2001; 
Armandi et al, 2003; Pearce et al, 2003). Generally, the tasks/activities they associated with leadership were deemed to be secondary management tasks (i.e. communication and motivation). Nevertheless, it would seem that the leadership proponents suggest that leadership is an exalted concept, with nobler intentions than classical management (Zaleznik, 1977; Burns, 1978; Bennis and Nanus, 1985; Kotter, 1996, 2001; Tichy, 1997; Kent et al, 2001; Armandi et al, 2003; Pearce et al, 2003). To some extent, these ideas seem to render classical management irrelevant.

In this regard, the work of Zaleznik (1977) seems to represent the watershed between classical management and leadership. A few observations regarding the scientific rigour of this specific work are warranted. Firstly, only two CEOs were interviewed in connection with aspects of running a business. No information is divulged as to why and how these two CEOs were selected. The two CEOs responded very differently to the questions posed, hence Zaleznik's view of management and leadership - management being regarded as mundane, repetitive and problem-solving in nature, while leadership engages in transformational activities, requiring imaginative capabilities to direct affairs. Finally, a very important point that needs to be highlighted is that generalisations cannot be made beyond this study on two accounts. Firstly, researchers cannot be sure that the contexts, assumptions and other critical aspects of scientific research, including a causal relationship between the CEO response and success of the business, are compatible and hence allow for generalisations in the particular case(s). Secondly, from a statistical point of view, two items can hardly be considered representative of the population as a whole.

In addition, if the contemporary leadership literature is compared with the classical management literature, there seems to be no real difference, except that leadership represents a partial view of classical management and the tasks/activities are mainly associated with secondary rather than primary management tasks (Zaleznik, 1977; Burns, 1978; Kotter, 1996,2001; Tichy, 1997; Bennis and Nanus, 1985; Kent etal, 2001; Armandi etal, 2003; Pearce etal, 2003 versus especially Barnard, 1938; Follett, 1925 in Metcalf and Urwick, 1940; Fayol, 1949; Gilbreths in Spriegel and Myers, 1953; Drucker, 1955, 1989, 2003; Simon, 1962; McGregor in Bennis and Schein, 1966; Koontz and Weihrich, 1988; Ulrich etal, 1999; Fells, 2000; Humphreys and Einstein, 2000; Collins, 2001; Witzel, 2002; Bruch and Ghoshal, 2004; Wren, 2005). The two concepts are rather inextricably intertwined. If one considers the meaning of classical management presented so far, it seems that progress was achieved over the years in establishing and advancing the body of knowledge underpinning classical management, which naturally includes leadership.

Classical management can therefore be described as the process of creating and maintaining an environment in which employees, individually and collectively, can perform to achieve the purpose of the organisation, namely efficiently satisfying customers (Nienaber, 2007) in the long run. This description of classical management is congruent with definitions proposed by Taylor (1911), Barnard (1938), Follett (1925, in Metcalf and Urwick, 1940), Fayol (1949), Gilbreths (in Spriegel and Myers, 1953), Drucker (1955, 1989, 2003), Koontz and Weihrich (1988), Moss-Kanter (1997), Ulrich et al. (1999), Collins (2001), Witzel (2002), Magretta (2003), Bruch and Ghoshal (2004) and Wren (2005). In studying the definitions of the said authors, certain themes emerge. These themes are deemed to be the constituent parts of classical management. It should be noted that not all authors use the same labels to identify these themes, nor do they 
all explicitly refer to these themes, nor do they all refer to all of these themes. For purposes of this paper, we have grouped the approaches to management and leadership into categories according to dominant themes discussed. This classification is provided in Table I, with an indication of the key features, key limitations and authors deemed to be part of each category.

Table I justifies a number of observations, of which the following three are possibly the most significant:

(1) The above classification differs from the general approaches in the literature, usually classified into the scientific management era, social person era and modern era, though it reflects similar ideas based on the management tasks, be they primary or secondary, and the comprehensiveness with which they are discussed.

(2) The date of the first publication relating to classical management is significant. The Industrial Revolution started in the late eighteenth century $( \pm 1,750)$ and lasted until the early nineteenth century (Marx and Churr, 1981). This means that the first publication on classical management appeared during the Industrial Revolution. The Industrial Revolution represented an awakening, resulting in large-scale social, economic and technological changes, stripping aristocrats of their monopoly of social, economic and political status. During this period, it was realised that technical skills alone were insufficient to sustain successful business performance in the long run; management training was required to ensure the latter (see for example the history of the Berlin porcelain manufacturers 1751-1780, Hetjens-Museum, Dusseldorf, Germany. Brochure). Another observation regarding the dates of the different publications is that by the time the leadership publications appeared, classical management, which included leadership, was well established.

(3) The social, economic and political landscapes of societies have changed since the Industrial Revolution. Technological advances have improved production techniques and ergonomics; agriculture has diminished as a contributor to GDP, while manufacturing rose and declined and currently services and knowledge management dominate most economies. It stands to reason that different skills are needed to prosper in different economies.

\section{Empirical study}

The problem studied was whether the views of a select group of manager-students on management and leadership differed from classical management theory. As such, the nature of the problem studied necessitated an exploratory-descriptive approach. Specifically, the final-year MBA students of the Graduate School of Management (GSM) at the University of Pretoria were approached to participate in a survey. The aim of the research was to describe which tasks/activities these particular respondents deem to constitute classical management, and can be divided into general management and leadership, and whether these views were different from the classical management theory.

The survey was conducted among the final-year MBA students at the GSM, University of Pretoria, consisting of two groups. The one group represented part-time students and the other group modular students. All of these students are employed in 


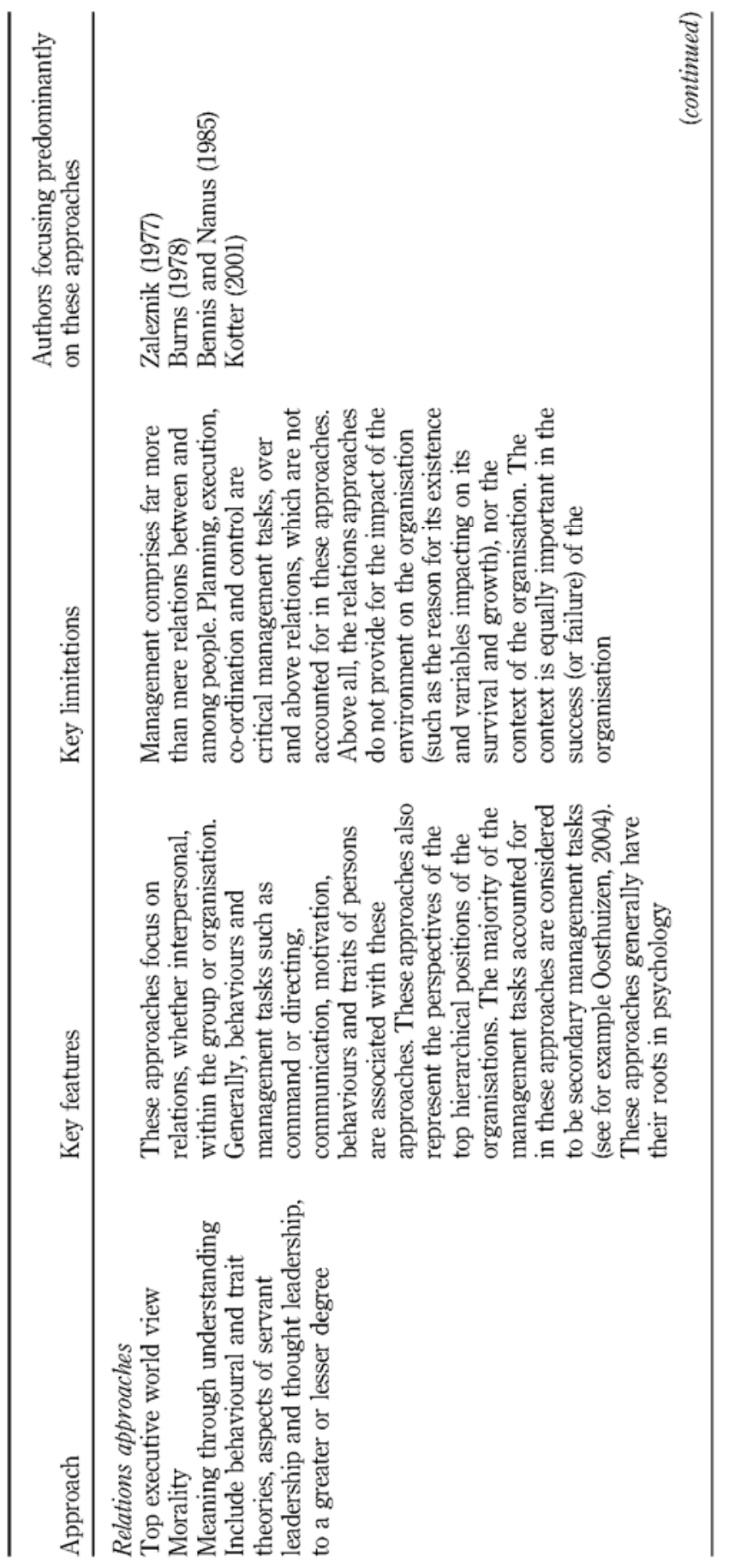

Table I.

Classification of management and leadership approaches 


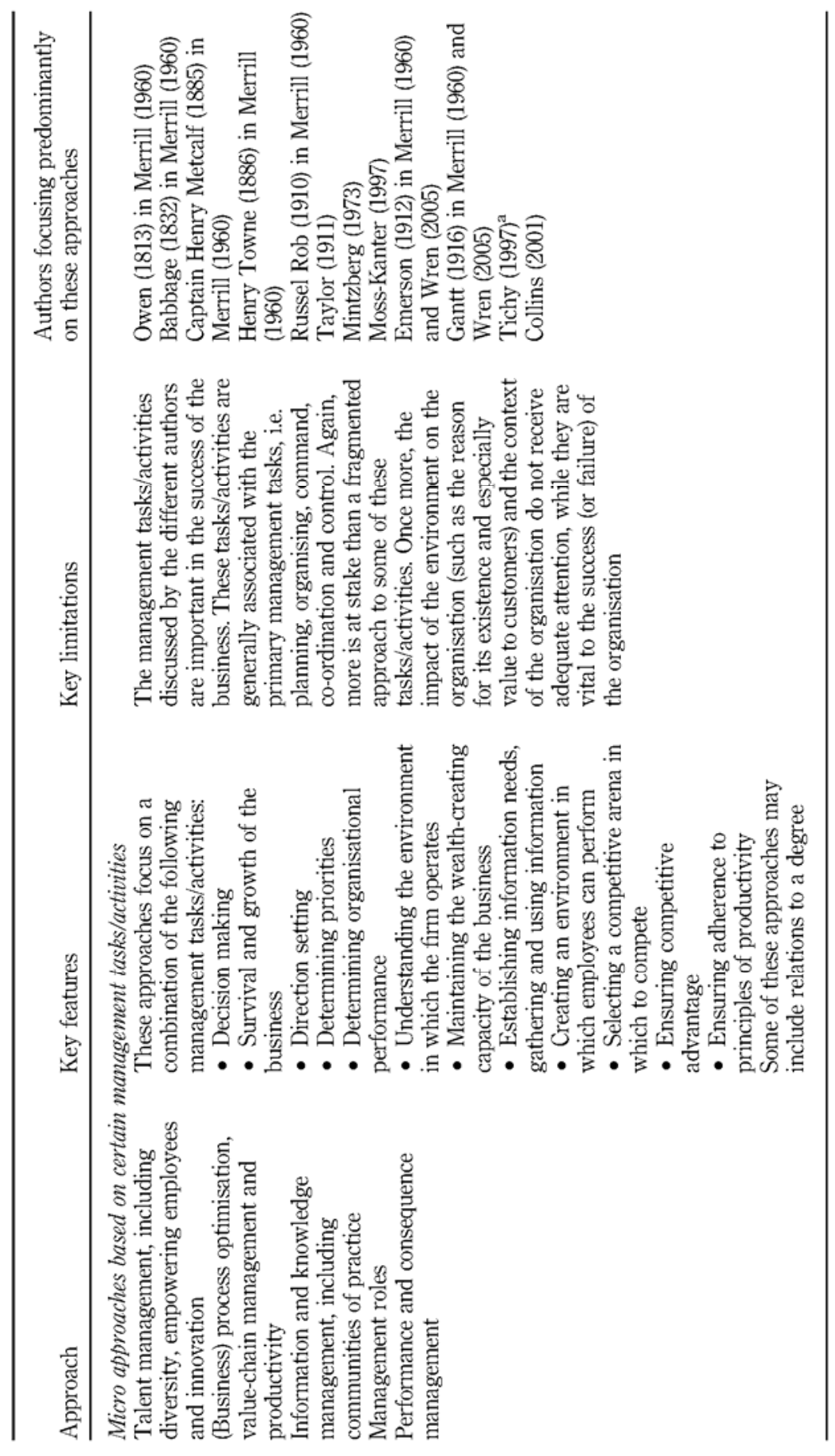




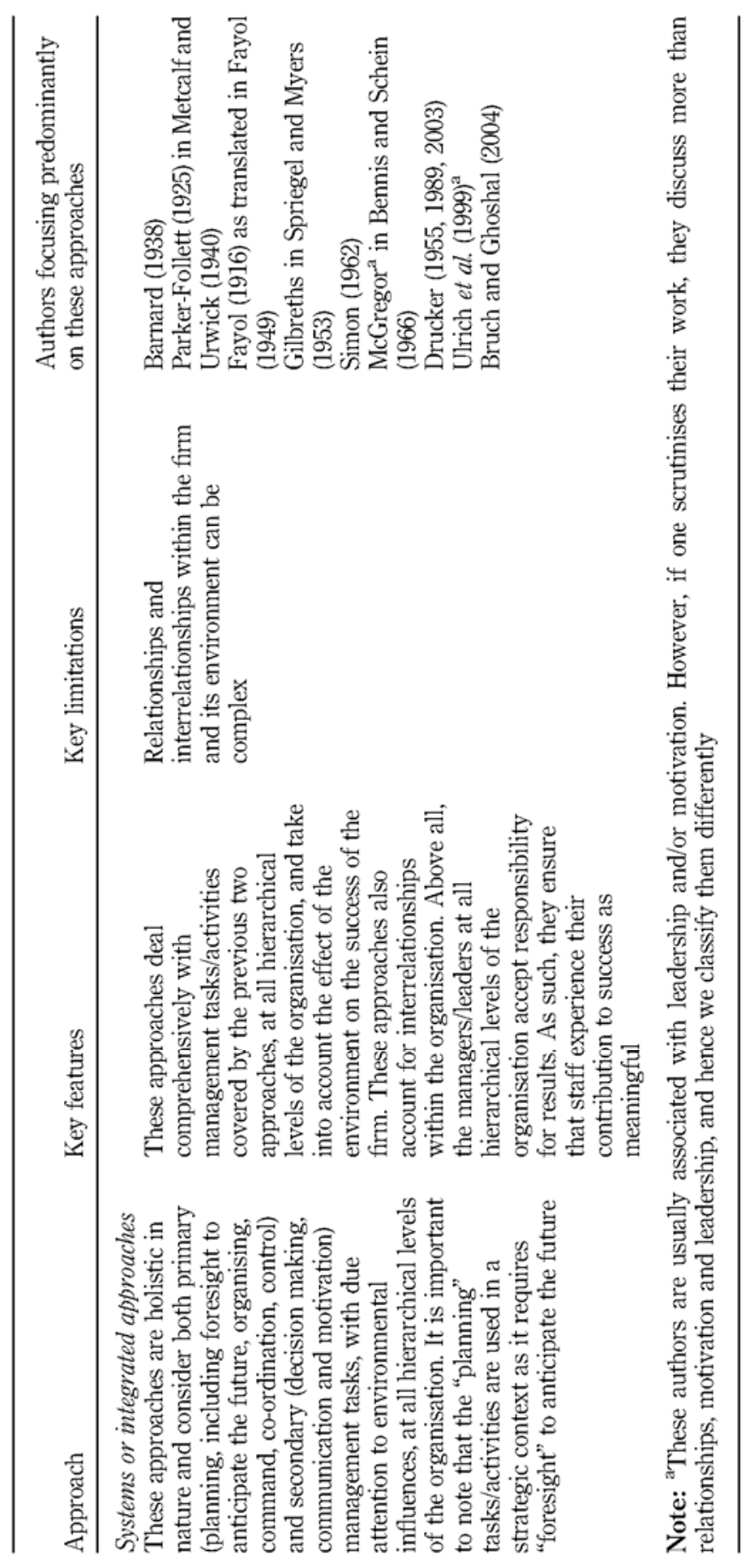

Table I. 
management positions in their respective organisations. A structured questionnaire was used in the survey. Respondents were required to indicate which option was most applicable, in their view. The first part of the questionnaire covered demographics, while the second part covered definitions of general management and leadership. The final part covered the tasks/activities of general management and leadership as represented in the approaches set out in Table I.

After the questionnaire had been constructed, the Department of Statistics at the University of Pretoria was approached to assist with possible analysis techniques. Given the qualitative nature of the information required, it was suggested that a descriptive technique be used. Hence, two-way frequency tables were used to analyse the results.

The survey was completed between 10 and 15 May 2006 by a total of 61 respondents. Of the 61 completed questionnaires, 60 (98 per cent) were usable. The results of the survey are presented below.

\section{Results of survey}

The demographics of the respondents can be summarised as follows:

- The majority (41 or 69 per cent) were from the private sector (and the companies they represented were deemed to be part of successful global enterprises).

- The majority (15 or 25 per cent) were from the finance, real estate, business services and insurance sectors; followed by 7 (12 per cent) from community and social services; 6 (10 per cent) each from the wholesale, retail and motor trade, transport and communication and general government services; and the remaining 20 (33 per cent) from other industries.

- About 42 (71 per cent) of respondents were employed by large businesses, that is businesses employing in excess of 100 employees and/or with a turnover in excess of R5 million.

- About 23 (38 per cent) indicated that they were English-speaking, 21 (35 per cent) were Afrikaans-speaking and the remainder spoke other indigenous languages.

- About 25 (42 per cent) were middle managers, followed by 11 (18 per cent) senior executives, 9 (15 per cent) senior management; 8 (13 per cent) were specialists and the remainder junior management.

- About 44 (73 per cent) were males and the remainder females; their ages varied between 25 and 52 years and they had been in management positions between 1 and 20 years.

- All indicated that they had attended management/leadership training programmes to a greater or lesser degree, with the majority (40 or 67 per cent) at least a team leader programme; followed by 29 (48 per cent), middle management programme; 22 (37 per cent), a supervision programme; 18 (30 per cent), a leadership programme; 11 (18 per cent), a senior management programme, and 9 (15 per cent), an executive management programme.

The second section of the questionnaire required respondents to indicate which one of the listed definitions corresponded most closely to his or her view of general 
management and leadership, respectively. Only 42 (70 per cent) respondents complied with the request, which is summarised in Table II.

The majority of respondents indicated that general management was the management of a total enterprise or autonomous sub-unit, followed by being "responsible for the performance of the business, especially survival and growth" and "an ability vested in people influencing performance positively, primarily by showing regard for people". In the case of leadership, the pattern was the opposite.

Only 6 (14 per cent) respondents indicated that they deemed general management and leadership to be exactly the same. However, looking carefully at the first three definitions presented in the questionnaire, there are not clear differences - all are concerned with the successful performance of the total organisation. Hence, another 20 (48 per cent) viewed general management and leadership to be similar, as they have indicated any of the first three definitions to belong under both general management and leadership. Only 16 (38 per cent) viewed general management and leadership to be quite different, as they indicated any of the first three definitions to be general management and either the fourth or fifth definition to be leadership, or vice versa. As a consequence, we have concluded that 62 per cent of the respondents deemed general management and leadership to be similar, while only 38 per cent deemed it to be different.

The views of all (60) respondents with regard to the tasks/activities constituting general management and/or leadership are shown in Figure 1.

As shown in Figure 1, not all of the 60 respondents responded to all tasks/activities, hence the gap. A few of the tasks/activities were associated with general management by the majority of the respondents, namely task 10 (determine what goods and services customers desire) and task 25 (productivity). A few of the tasks/activities were associated with leadership by the majority of the respondents, namely task 2 (anticipate the future), task 3 (set a vision) and task 22 (select a competitive arena). Most of the tasks/activities were associated with general management and leadership by the majority of the respondents - the rest of the tasks. The allocation of the tasks/activities is shown in Figure 2.

All of the tasks/activities shown in Figure 2 are associated with classical management, which includes leadership. According to the responses shown in Figures 1 and 2, the few tasks/activities associated with leadership by the majority of respondents do not entirely correspond to these typical tasks/activities. 
Figure 1.

Responses to tasks/activities forming part of general management/leadership

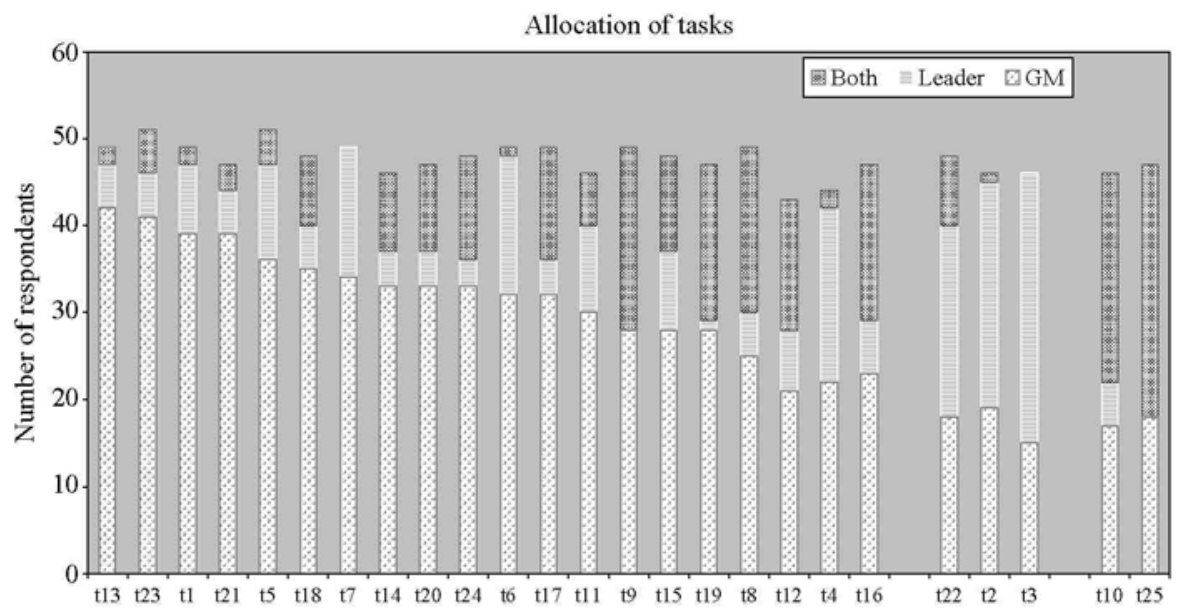

Figure 2.

Views of respondents regarding tasks/activities constituting general management/leadership

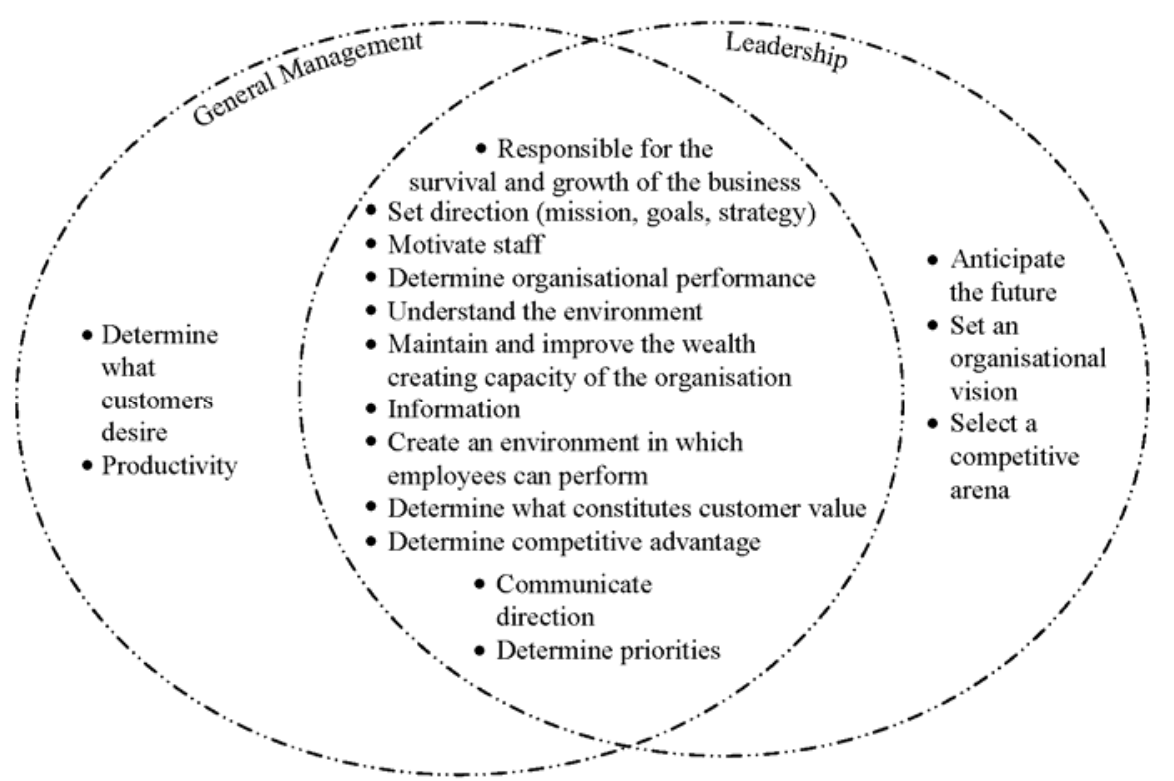

Classical management authors associate leadership with the primary tasks of command and co-ordination, while leadership proponents of the mid-1970s associate leadership with the primary task of command, and secondary tasks such as communication and motivation. The respondents associated leadership with the primary task of planning, which is strategic in nature.

Finally, in comparing the respondents' definitions of general management/ leadership with the tasks/activities allocated to each there seems to be a conflict. 
Unknowingly, the majority of respondents deemed general management and leadership to be the same and their allocation of tasks/activities confirms their definitions of the concepts. These views are congruent with classical management theory. However, 16 (38 per cent) respondents deemed general management and leadership to be different. However, in terms of the allocation of the tasks/activities to general management and leadership, they have failed to indicate a difference.

\section{Conclusions}

The information presented in this paper demonstrates that there is a body of knowledge underpinning classical management which is still relevant today. This body of knowledge is all-encompassing, holistic in nature, and includes leadership. The original works pertaining to classical management are not readily available today, and their unavailability may hamper the acquisition of knowledge in this field. However, training based on an accurate reflection of these works could rectify this situation.

The importance of command and co-ordination as management tasks, and hence, leadership, cannot be disputed. However, there seems to be a discernible pattern in leadership publications based on the assumption that leadership is a separate and predominant concept, and these presentations seem to be enthusiastically embraced despite their lack of scientific rigour. This situation gives rise to questions whether factors such as:

- the unavailability of the original classical management works;

- classical management being a young discipline;

- the nature of the social sciences; and

- lack of scientific rigour applied by researchers contribute to this state of affairs.

Be that as it may, the importance of scientific rigour to research, especially in the social sciences, cannot be overestimated. Scientific rigour includes the objective and methodical way in which observations are made and evidence collected, as well as the extent to which all other explanations are invalidated or refuted.

Finally, from the findings of the empirical study, one could conclude that the respondents surveyed viewed general management and leadership as being similar. Furthermore, their views on general management/leadership seem to be congruent with the views of the seminal authors on classical management. The exception was the three tasks deemed by some to be the primary responsibility of leadership, i.e. anticipating the future, setting an organisational vision and selecting a competitive arena. As these three tasks are considered in classical management theory as part of the planning task of general management, that is, strategic in nature, there is not really a contradiction here between classical management theory and practice, (according to the respondents' views leadership activities form part of the primary tasks, specifically the planning task and rather than command and co-ordination tasks as proposed by the classical theory. Thus, in terms of "kind of task" it corresponds, though in terms of the precise task, it differs).

With the information at our disposal, it seems appropriate to recommend that further research be done in this area to contribute to clarity on this question. This could perhaps assist management teachers in spreading an accurate message of management and leadership both being vital components of organisational success. 


\section{Managerial and theoretical implications}

The information presented in this paper demonstrates that a group of practitioners view "management" and "leadership" as similar. Furthermore, they were unable to distinguish between tasks/activities constituting each. In a way, this kind of response is not surprising as the manager/leader incumbent must discharge of the responsibilities of both manager and leader. The former, according to the classical management theory, comprises planning, organising and control and the latter command and co-ordination.

Knowledge about management and leadership is imperative to ensure technical skills of incumbents in management/leadership positions. Technical skills are required to ensure the organisation's preferred competitive position in the market and endurance of the organisation in the long term. In this regard, the practitioners have a responsibility to acquaint themselves with the body of knowledge underpinning management/leadership that can guide them towards excellence. At the same time, academics have the moral responsibility to ensure that a management/leadership body of knowledge is available to practitioners. This body of knowledge should comply with scientific characteristics, including, first and foremost, being accurate, fact-based, relevant and objective. Ultimately, this (scientific) body of knowledge guides practitioners towards success. Knowledge fraught with inaccuracies, emotional claims and "flavour of the month gospel" promotes buccaneering that causes "bewilderment" which ultimately results in failure.

It is acknowledged that contemporary authors use labels that resonate with their contemporary audiences. At the same time, it should be noted that labels are not important, but rather the content identified by the labels. This paper shows the enduring contribution of classical management. Furthermore, it discusses issues of value and contemporary relevance. It also provides a framework for managerial success. As such, it would seem an opportune time to reacquaint ourselves (both academics and practitioners) with the original classical management works that laid the foundation upon which we could build and make a lasting contribution to the science of management (which includes leadership).

\section{References}

Armandi, B., Oppedisano, J. and Sherman, H. (2003), 'Leadership theory and practice: a 'case' in point”, Management Decision, Vol. 41 No. 10, pp. 1076-88.

Barnard, C.I. (1938), The Functions of the Executive, Harvard Business School Press, Boston, MA.

Bennis, W. and Nanus, B. (1985), Leaders: Strategies for Taking Charge, The Dryden Press, Dryden, NY.

Bennis, W. and Schein, E. (Eds) (1966), Leadership and Motivation Essays of Douglas McGregor, Massachusetts Institute of Technology, Cambridge, MA, with the collaboration of Caroline McGregor.

Bruch, H. and Ghoshal, S. (2004), A Bias for Action: How Effective Managers Harness their Willpower, Achieve Results and Stop Wasting Time, Harvard School Publishing, Boston, MA.

Burns, J.M. (1978), Leadership, Harper and Row, New York, NY.

Collins, J. (2001), Good to Great: Why Some Companies Make the Leap and Others don't, HarperCollins, New York, NY.

Drucker, P.F. (1955), The Practice of Management, Heinemann, London. 
Drucker, P.F. (1989), The Practice of Management, Heinemann, London.

Drucker,P.F. (2003), On the Profession of Management, HarvardBusiness School Press, Boston, MA.

Fayol, H. (1949), General and Industrial Management, Pitman, London, translated from the French by Constance Storrs.

Fells, M.J. (2000), "Fayol stands the test of time", Journal of Management History, Vol. 6 No. 8, pp. 345-60.

Humphreys, J.H. and Einstein, W.O. (2000), "Nothing new under the sun: transformational leadership from a historical perspective", Journal of Management History, Vol. 44 No. 1, pp. 85-95.

Kent, T.W., Crotts, J.C. and Azziz, A. (2001), "Four factors of transformational leadership behaviour", Leadership and Business Development Journal, Vol. 22 No. 5, pp. 221-9.

Koontz, H. and Weihrich, H. (1988), Management, 9th ed., McGraw-Hill, Singapore.

Kotter, J.P. (1996), Leading Change, Harvard Business School Press, Boston, MA.

Kotter, J.P. (2001), "What leaders really do", Harvard Business Review, Vol. 79, pp. 85-96.

McMahon, D. and Carr, J.C. (1999), "The contributions of Chester Barnard to strategic management theory", Journal of Management History, Vol. 5 No. 5, pp. 228-40.

Magretta, J. (2003), What Management is: How it Works and Why it's Everyone's Business, Free Press, New York, NY.

Marx, F.W. and Churr, E.G. (1981), Grondbeginsels van die bedryfsekonomie, HAUM, Pretoria.

Merrill, H.F. (Ed.) (1960), Classics in Management, American Management Association, New York, NY.

Metcalf, H.C. and Urwick, L. (Eds) (1940), Dynamic Administration: The Collected Papers of Mary Parker Follett, Harper, New York, NY.

Mintzberg, H. (1973), The Nature of Managerial Work, Harper and Row, New York, NY.

Moss-Kanter, R. (1997), On the Frontiers of Management, Harvard Press, Boston, MA.

Nienaber, H. (2007), "Assessing the management status of South Africa”, EBR, Vol. 19.

O'Connor, E.S. (2000), "Integrating Follet: history, philosophy and management", Journal of Management History, Vol. 6 No. 4, pp. 167-90.

Oosthuizen, T.F.J. (Ed.) (2004), Management Tasks for Managerial Success, 2nd ed., FVBC, Roodepoort.

Pearce, C.L., Sims, H.P. Jr, Cox, J.F., Ball, G., Schnell, E., Smith, K.A. and Trevino, L. (2003), "Transactors, transformers and beyond: a multi-method development of a theoretical typology of leadership", Journal of Management Development, Vol. 22 No. 4, pp. 273-307.

Rodriques, C.A. (2001), "Fayol's 14 principles of management then and now: a framework for managing today's businesses", Management Decision, Vol. 39 No. 10, pp. 880-9.

Simon, H.A. (1962), Administrative Behaviour, Macmillan, New York, NY.

Spriegel, W.R. and Myers, C.E. (Eds) (1953), The Writings of the Gilbreths, Irwin, Homewood, IL.

Taylor, F.W. (1911), The Principles of Scientific Management, Dover, New York, NY.

Tichy, N.M. (1997), The Leadership Engine: How Winning Companies Build Leaders at Every Level, Harper-Collins, New York, NY.

Ulrich, D., Zenger, J. and Smallwood, N. (1999), Result-based Leadership, Harvard Business School Press, Boston, MA.

Witzel, M. (2002), Builders and Dreamers: The Making of Management, Pearson Education, Harlow. 
Wren, D.A. (2001), "Henri Fayol as strategist: a nineteenth century corporate turnaround", Management Decision, Vol. 39 No. 6, pp. 475-87.

Wren, D.A. (2005), The History of Management Thought, 5th ed., Wiley, London.

Wren, D.A., Bedeian, A.G. and Breeze, J.D. (2002), "The foundations of Henri Fayol's administrative theory", Management Decision, Vol. 40 No. 9, pp. 906-18.

Zaleznik, A. (1977), "Managers and leaders: are they different?", Harvard Business Review, May-June, pp. 67-78. 